\title{
Chapter 17 \\ House Prices and Financial Stability: An Australian Perspective
}

\author{
Michele Bullock and David Orsmond
}

\section{Introduction}

As in a number of countries, housing prices in Australia have increased at a rapid pace over the past couple of decades, particularly in the major cities. These price rises have raised a range of concerns, including for housing affordability. As a result, there has been much debate about the types of policies that could ease the growth in housing prices.

While acknowledging the broader societal impacts of high and rising housing prices, the Reserve Bank of Australia (RBA) has not seen managing the pace of housing price rises per se as within its policy remit. Rather, the RBA's concern has been that the associated build-up in household debt and other dynamics in the housing sector have raised concerns about the health of borrowers' balance sheets and, therefore, financial stability. If realised, these risks could have a detrimental impact on the broader economy. Like many other countries, the RBA and other policymakers have considered various ways to address these risks. This chapter outlines this approach and recent experiences.

\section{The Housing Market in Australia}

Australia is a large country geographically but its population is concentrated in a small number of cities. From a population of close to 25 million, around 15 million live in the largest five cities, with 10 million people in Sydney and Melbourne alone.

M. Bullock

Financial System Group, Reserve Bank of Australia, Sydney, NSW, Australia

e-mail: bullockm@rba.gov.au

D. Orsmond $(\bowtie)$

Financial Stability Department, Reserve Bank of Australia, Sydney, NSW, Australia

e-mail: orsmondd@rba.gov.au 
In the decade to mid-2017, the combined population of the five largest cities grew by $22 \%$, accounting for around three-quarters of Australia's population growth, which was one of the fastest within the OECD. It is unsurprising then that there has at times been pressure on the housing stock, particularly in Sydney and Melbourne.

Housing prices in Australia have risen substantially since the 1980s. Part of this reflects the strong growth in the economy and household incomes over the past few decades. But housing prices have also increased relative to incomes. The factors driving this upward shift in the relative price of housing were primarily twofold (Kohler and van der Merwe 2015; Reserve Bank of Australia 2003, 2014). First, the decline in average nominal interest rates as a result of the structural decline in inflation in the 1990s meant that borrowers could service larger loans out of their current income than they had been able to in the past. Second, deregulation of the financial system reinforced this trend by removing many of the previous constraints on credit supply to households. By the mid-2000s, this structural transition seemed largely complete and the average housing price settled at around four times average household disposable incomes (Fig. 17.1).

In more recent years, however, housing prices have grown quite strongly again, particularly in Sydney and Melbourne (Fig. 17.2). Low interest rates, relatively strong population growth and interest by investors (foreign and domestic) all contributed to a strong demand for residential property. Coupled with zoning

(a)

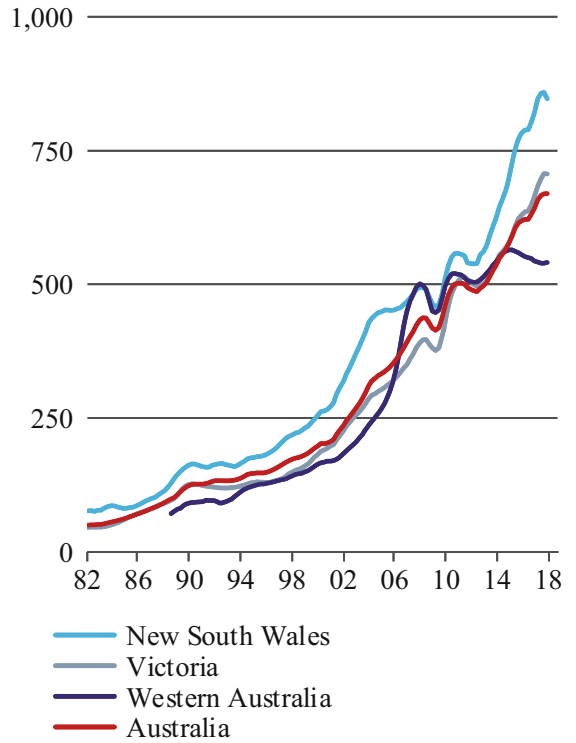

(b)

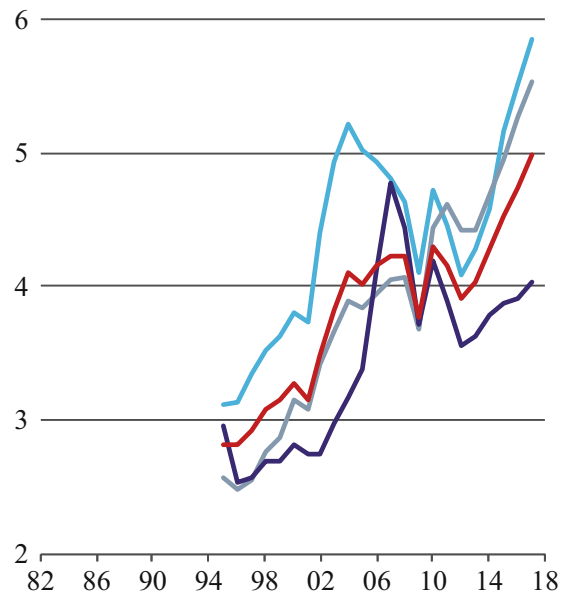

Source: ABS (2017); CoreLogic (2018); RBA (2018)

Fig. 17.1 (a) Dwelling prices (yearly means, $\$ 000$ s) (b) Price-to-income ratios. Note: CoreLogic data is commercial and not for publication or further distribution without approval. Graphs using this data can be published with appropriate attribution 

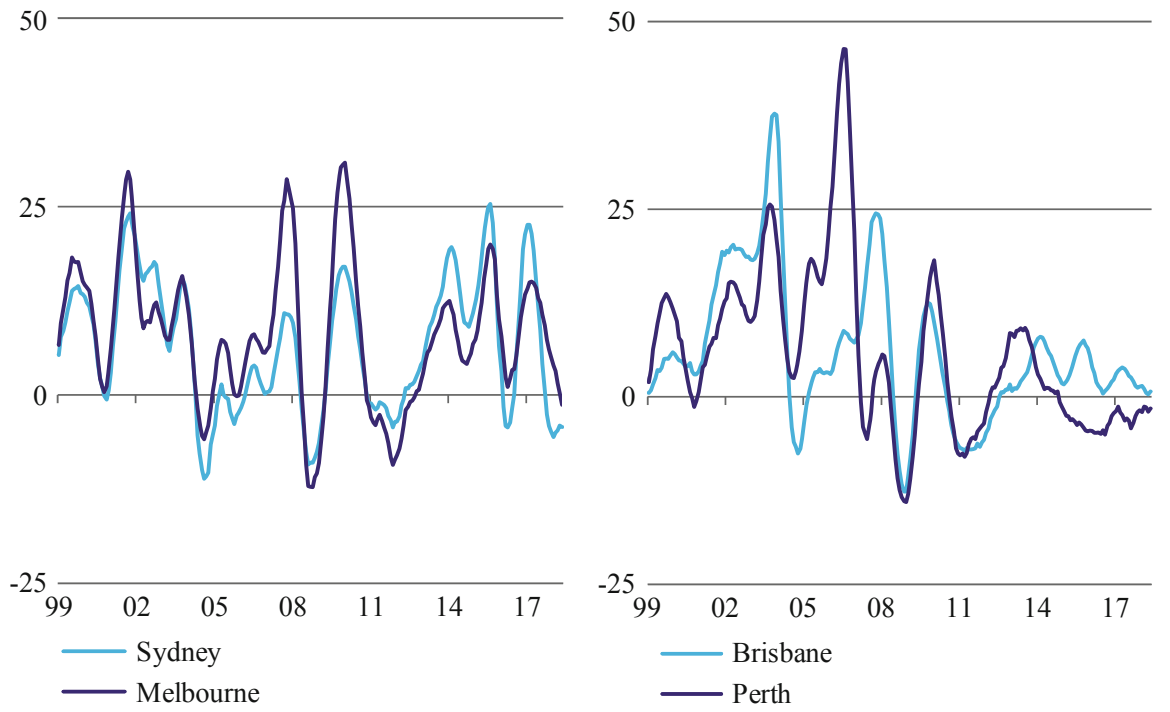

Source: CoreLogic (2018); RBA (2018)

Fig. 17.2 Housing price growth (6-month-ended annualised; seasonally adjusted). Note: CoreLogic data is commercial and not for publication or further distribution without approval. Graphs using this data can be published with appropriate attribution

restrictions and other supply constraints, this resulted in housing prices increasing by around 20\% a year in Sydney and Melbourne in 2013 and 2014 (Hsieh et al. 2012). While the pace of growth of overall housing credit was more modest than in previous housing cycles, investor credit was starting to rise rapidly. Housing price growth eased in 2015 but increased again through 2016 and 2017. By the end of 2017, the average price was around five times average household incomes. In contrast, the slowdown in the mining investment boom saw housing price declines in Perth and, to a lesser extent, Brisbane, which are both located in the more miningintensive states of Australia.

These developments have generated a lot of attention. Housing affordability has consistently been a topical issue in Australia, with much discussion around issues such as how to ease constraints on supply, policies to assist first home buyers, tax incentives for investors and the impact of foreign buyers on the housing market. ${ }^{1}$ The RBA's concerns, however, have been focused on the potential implications of broad developments in the housing sector for financial stability and macro-financial risks. There have been a couple of elements to this.

First, the rise in housing prices has been accompanied by a rise in the ratio of household debt to income. After stabilising at around $120 \%$ of income from the mid-2000s, the household mortgage debt ratio has since risen to $140 \%$ (Fig. 17.3).

\footnotetext{
${ }^{1}$ For the RBA submissions to the various inquiries into housing and housing finance over the past decade that outline these issues, see https://www.rba.gov.au/publications/submissions/housingand-housing-finance/
} 


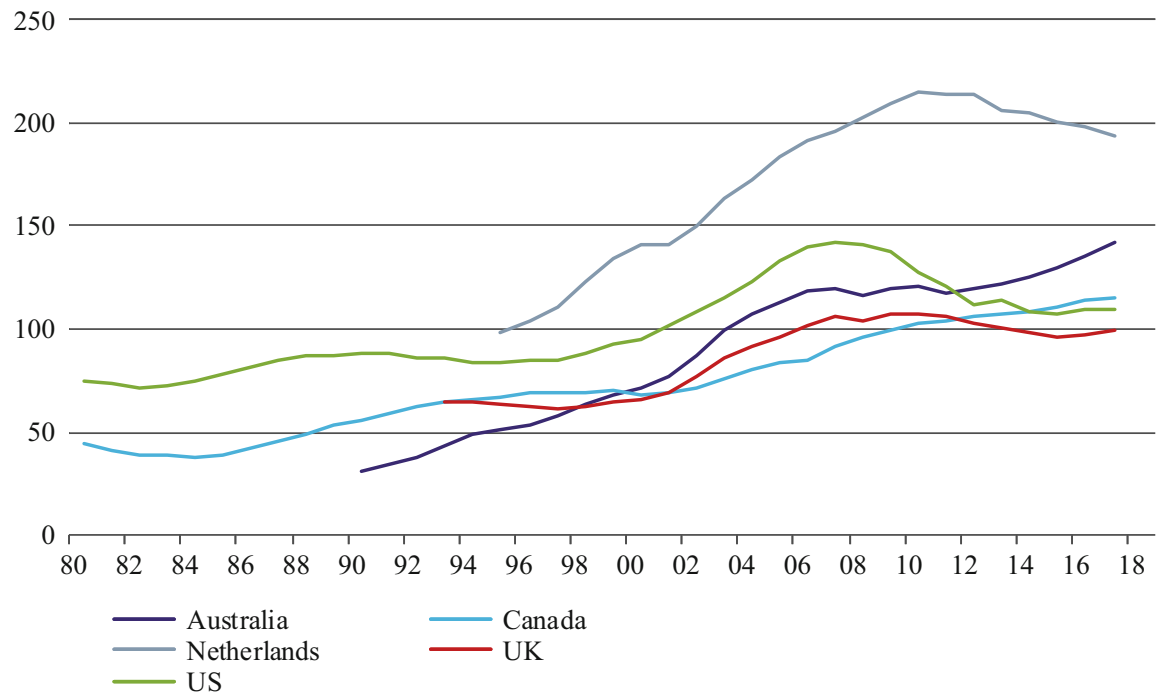

Source: National central banks and statistical offices; RBA (2018); OECD (2018); Thomson Reuters; ABS (2018); Bank of England (2018); Statistics Canada (2018); Statistics Netherlands (2018); US Federal Reserve (2018)

Fig. 17.3 Household mortgage debt-to-income ratio

This ratio is high relative to many other (but not all) advanced economies and raises issues about the resilience of household balance sheets in the event of an adverse shock to the housing sector and/or the economy.

Second, the Australian financial system is heavily weighted towards housing lending. Over the past decade, the largest Australian banks (which account for around $80 \%$ of the assets of the deposit-taking institutions) have steadily increased their exposure to housing so that around $60 \%$ of banks' lending is now for mortgages (Fig. 17.4). There have also been concerns that strong competition among mortgage lenders has resulted in lending standards becoming too relaxed. While stress tests indicate that banks are sufficiently well capitalised to handle a rise in loan delinquencies combined with a large fall in housing prices, a substantial downturn in the housing market could have implications for the economy more broadly.

These risks might be realised in a number of ways. First, while households often have sizeable pre-payment buffers, the high debt-to-income ratio can make them vulnerable to an adverse economic shock, with implications for household consumption. Households might also become forced sellers, resulting in downward pressure on housing prices and possibly inducing further selling. In addition, there has been a significant increase in the amount of interest-only lending, which can leave households with higher debt than for principal-and-interest loans and, in the event of sharp downturn in the housing market, possibly with negative equity. These developments would also weigh on banks' asset performance and profitability.

Second, investor activity could amplify the housing cycle. Unlike in many other countries, most of the rental stock of housing in Australia is owned by households as an investment, which boosts the level of household debt. Through 2013 and 2014, 
(a)

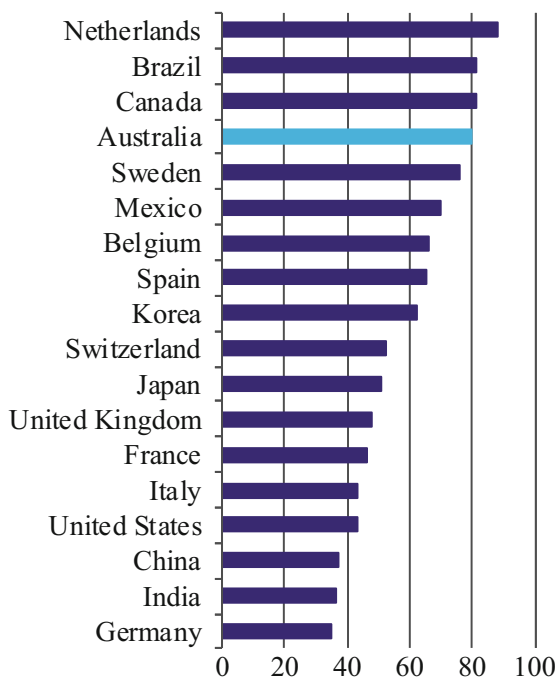

Source: BIS (2018); RBA (2018); World Bank (b)

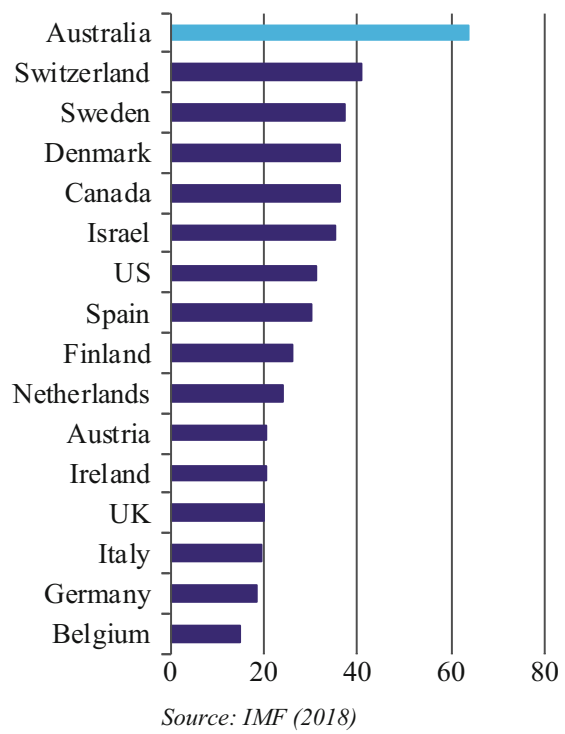

Fig. 17.4 (a) Banking system concentration (market share of the five largest banks) (b) Mortgage lending concentration

as the housing market was picking up, growth in lending to housing investors was rising by over $10 \%$ a year. In Australia, the tax deductibility of interest on investment loans and favourable rate of capital gains tax encourage households to borrow to purchase investment properties and not to pay down the principal. The substantial growth in investor lending therefore raises concerns about possible pro-cyclical behaviour of housing investors - the more housing prices rise, the more investors borrow to invest, potentially pushing up housing prices and debt levels further. If the housing market then turns down, and the prospect of capital gains diminish, these investors might sell ahead of expected price falls, amplifying the housing cycle (Reserve Bank of Australia 2017). This would have wider flow-on effects to owneroccupier households, which would find the price of their most important asset falling while they have a high level of debt.

Finally, the residential development cycle might also exacerbate the housing cycle, particularly for medium- and high-density apartment buildings, whose share has increased in recent years from around one-quarter to one-half of the new housing stock. High prices typically bring forth a supply response. But the lag in supply of new apartments coming on stream can mean that by the time it does, there is an oversupply. If the oversupply is significantly large, it would have implications for developers, and hence the performance of banks' property books. It would also have implications for households if they have contracted to purchase property in advance of construction on the expectation of making a subsequent capital gain. Again, this would have implications for bank balance sheets. 


\section{The Policy Response}

In Australia, prudential regulation of financial institutions is the responsibility of the Australian Prudential Regulation Authority (APRA). APRA is tasked with protecting the interests of depositors, policyholders and superannuation (pension) fund members by maintaining the safety and soundness of financial institutions. Its mandate also requires it to promote financial stability more broadly. APRA has the usual regulatory and supervisory tools at its disposal to achieve this, but can also use these tools for what are now often-termed 'macroprudential' purposes.

The RBA has responsibility for financial stability more broadly. The RBA interprets this to mean that it should aim to minimise the possibility that instability in the financial sector or broader macro-financial risks threaten the real economy. The RBA does not, however, have any specific tools that it can use to deal with financial stability issues, though in stress periods it can provide liquidity to solvent institutions. While its monetary policy framework provides the RBA with the flexibility to set policy to achieve its broad objectives over time, including financial stability, addressing systemic risk typically involves identifying and communicating risks and working with other financial regulators to address them. The Council of Financial Regulators (which comprises the RBA, APRA, the Australian Securities and Investments Commission (ASIC) and the Australian Treasury) plays an important role by providing a forum for the sharing of information and views in this regard. It meets quarterly, although ongoing interactions are undertaken more frequently at all levels of these agencies. The Council has no powers of its own. So if stability risks are building, it is usually APRA that has the most appropriate tools to deal with not only risks to individual institutions but also risks to the system as a whole.

The financial stability risks associated with the recent increase in household indebtedness and housing prices generated a number of policy responses. As has historically been the case, the main approach by the regulators was to focus on setting appropriate lending standards. In response to the emerging risks in the housing sector, at end 2014 APRA announced that it would increase its supervisory oversight on mortgage lending (APRA 2014). Specifically, it indicated that it would be paying increased attention to higher-risk mortgage lending such as high loan-toincome loans, high loan-to-valuation (LVR) loans, interest-only loans to owner occupiers and loans with very long terms. It set out clear prudential expectations that lenders' serviceability tests for new borrowers must incorporate an interest rate buffer that was comfortably above (by at least 2 percentage points) the prevailing loan product rate. APRA also indicated that the prevailing strong growth in lending to property investors was a particular area of concern and set a new benchmark where growth in an institution's portfolio of investor loans of more than $10 \%$ would be an 'important risk indicator for APRA supervisors in considering the need for further action'. At the same time, ASIC took steps to reinforce the 'responsible lending' obligations that cover all lenders and ensure that loan serviceability is assessed to ensure that new borrowers do not overstretch their financial capacity to 
purchase property or need to rely on expectations of future increases in housing prices to enable them to do so.

These policy steps were primarily designed to dampen the most risky competitive pressures and encourage banks to lend more prudently. But they also helped to improve the resilience of household balance sheets, essentially reducing the maximum loan size and ensuring that the borrowers that received loans were in the best position to service the loans thereafter. Growth in lending to property investors subsequently fell from over $10 \%$ to less than $3 \%$ annually while growth in credit to owner-occupiers actually increased (Fig. 17.5). The share of loans at LVRs of over $90 \%$ declined from $12 \%$ to $7 \%$. Growth in housing prices also eased.

Nevertheless, by 2016, housing activity was picking up again in Sydney and Melbourne, household debt was still rising faster than incomes, and growth in lending to property investors had started to rise again. So in early 2017, APRA, with the support of the Council of Financial Regulators, introduced further measures to bolster residential mortgage lending practices (APRA 2017). Apart from tightening somewhat further its 2014 guidelines on lending standard expectations, APRA indicated that it expected financial institutions to limit the flow of new interest-only lending for housing to $30 \%$ of their new lending (Fig. 17.5). To limit the risk of leakage, APRA also noted that it would be carefully examining trends in the level of warehouse funding by banks to non-bank lenders.

(a)

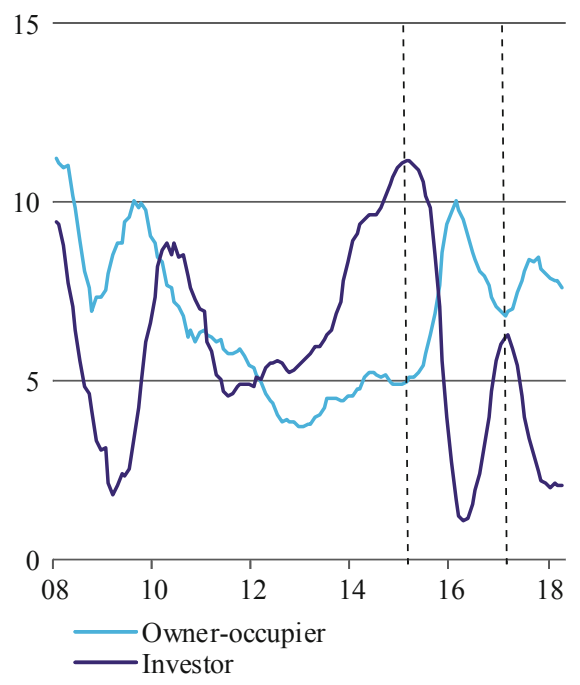

Source: APRA (2018); RBA (2018) (b)

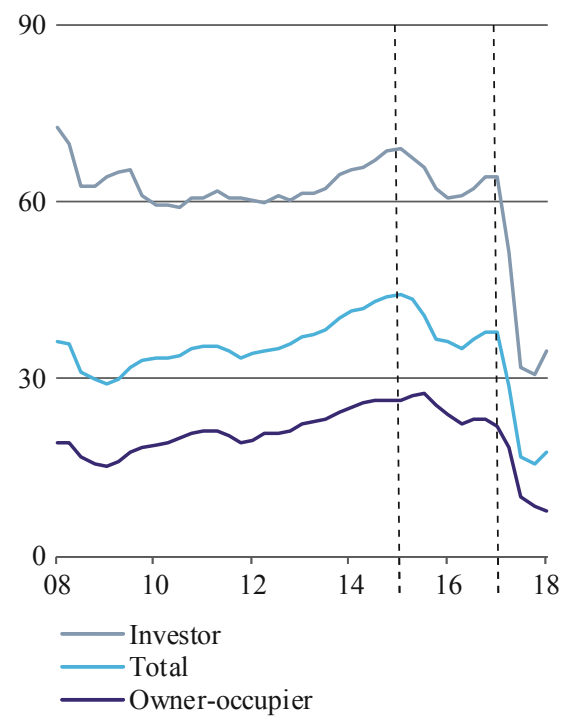

Fig. 17.5 (a) Housing credit growth (6-month-ended annualised) (b) Interest-only loan approvals share. Note: Dashed vertical lines in both panels of graph positioned in alignment with January 2015 and March 2017 
Since then, risks in the housing market have again eased. The share of new housing lending that is on interest-only terms has declined to around $16 \%$, well below the benchmark. There has also been less investor activity relative to owner occupiers and some signs of an increase in first home buyer activity. APRA has recently announced that the quality of new lending has improved to the extent that it will be able to remove the investor loan growth benchmark for individual institutions that meet certain requirements (APRA 2018). And while not a target in itself, growth in housing prices in Sydney and Melbourne has declined substantially, and in Sydney's case prices have even fallen a little in recent months.

\section{Reflections}

The Australian approach to addressing financial stability concerns has been heavily weighted towards setting appropriate prudential expectations, with relatively little use of prescriptive quantitative targets. While not an exhaustive list, there are four key issues that the recent experience has raised.

\subsection{How Is Effectiveness Evaluated?}

It is not always straightforward to measure the effectiveness of what have come to be known globally as 'macroprudential policies.' In Australia's case, the goal was to address financial stability risks by ensuring that banks and households were being appropriately prudent in their lending and borrowing decisions. But this broad policy goal is very difficult to measure with a high degree of accuracy. Instead, we can look to the specific impact of the measures taken-for example, the incidence of high-risk lending, pace of growth in investor loans and share of interest-only loans. By these metrics, the policies were apparently effective. But quantitative measures are difficult to calibrate and assess ex-post and in some cases have had only temporary effects, especially as other policies have continued to evolve. The benchmark on growth in investor lending introduced in 2014, for example, initially resulted in a sharp decline in the growth rate, but by early 2017 the growth rate was rising again. The $30 \%$ benchmark on the share of new interest-only loans introduced in 2017 was also materially overshot. But there appears to be continued demand for interest-only loans and there are signs that banks are looking to expand this category of lending again. More broadly, the global experience of the directed credit regimes of the 1960s and 1970s suggests that borrowers and lenders have an incentive to try to find ways to circumvent such controls. Noting this, the benchmark measures that have been used in Australia were always intended to be temporary while APRA put in place more permanent guidelines to address the associated concerns about lending standards. 
Whether these measures had an impact on the growth of housing prices is unclear. Certainly, housing price growth in both Sydney and Melbourne eased substantially following the APRA and ASIC measures that were introduced. But loan approvals and price growth had already started to ease prior to the 2017 measures. And there is evidence that the price declines have been more evident in higher priced properties over the past year - a segment that would be expected to be least affected by the portfolio benchmark measures as investors are more likely to purchase cheaper apartments than detached housing.

\subsection{Are Geographical Restrictions Helpful?}

In Australia, we did not implement geographic-specific policies to shore up financial stability concerns, though some individual banks decided to restrict lending to certain postcodes. While it was mainly Sydney and Melbourne where housing conditions were most buoyant, APRA acted to improve mortgage lending standards across the board. One argument for implementing geographical restrictions could be that the banks would meet the new guidelines by restricting lending everywhere except for Sydney and Melbourne, disproportionally affecting (say) the Brisbane apartment market (that was not experiencing sharp price rises) and exacerbate the price falls in Perth. This has not turned out to be the case. But more broadly, we are sceptical about the value of geographic policies. Apart from the fact that it looks increasingly like directed lending, other countries' experiences suggest that there are difficulties in calibration and in implementation of geographic constraints over the longer run (Reserve Bank of New Zealand 2016). And as long as the large cities continue to grow, there will be a continuing demand for new housing and, if anything, a challenge for supply to keep up with that demand. This suggests that policies directed at lending in specific areas are likely to be successful in restraining housing price growth only in the short term.

\subsection{Are There Undesirable Consequences?}

An important challenge is to respond to systemic risks in a manner that strikes a reasonable balance between facilitating the ongoing provision of credit to the economy while managing the risks and other flow-on effects, including during the transition from one equilibrium to another (less risky) one. As seen in other countries, the use of quantitative restrictions to curtail the provision of credit to borrowers perceived to be systemically risky can have undesirable consequences. These include adverse effects on competition and distributional considerations. In Australia, some small and regional lenders have argued that the benchmark on the growth of investor lending has entrenched market shares (COBA 2017). Further, the various restrictions constrain the size of a loan marginal borrowers can get, including 
some first home buyers, and so have equity and distributional implications, although in doing so they make the debt more manageable for these households. Another group of borrowers that could be adversely affected by the tighter lending standards are investors that paid deposits on off-the-plan housing on the assumption that they would be able to get finance on prevailing credit terms, and now find that they are unable to do so.

\subsection{How Are These Policies Likely to Evolve?}

Like many other countries, the use of quantitative benchmarks to bolster financial stability does not have a long history in Australia and there are still many lessons to learn. In principle, these types of tools have the potential to contain a range of financial stability risks, and the early evidence is that they can be effective, at least for a while. But in practice, their use poses a range of challenges including calibration, selecting the most effective tool for the specific risk, containing potential leakages, ensuring on-going political support, and knowing how to effectively integrate them into the more traditional supervisory and monetary policy frameworks. These issues are a challenge for all countries (including Australia) and hence it is likely that their operational practices and governance frameworks will continue to evolve.

\section{References}

Australian Prudential Regulation Authority. (2014, December 9). APRA outlines further steps to reinforce sound residential lending practices. Media Release.

Australian Prudential Regulation Authority. (2017, March 31). APRA announces further measures to reinforce sound residential mortgage lending practices. Media Release.

Australian Prudential Regulation Authority. (2018, April 26). APRA announces plans to remove investor lending benchmark and embed better practices. Media Release.

COBA. (2017, September). Submission to productivity commission inquiry into competition in the Australian financial system.

Hsieh, W., Norman, D., \& Orsmond, D. (2012, September 11-19). Supply-side issues in the housing sector. Reserve Bank of Australia Bulletin.

Kohler, M., \& van der Merwe, M. (2015, September 21-30). Long-run trends in housing price growth. Reserve Bank of Australia Bulletin.

Reserve Bank of Australia. (2003, November). Submission to the productivity commission inquiry on first home ownership.

Reserve Bank of Australia. (2014, February). Submission to the inquiry into affordable housing.

Reserve Bank of Australia. (2017, October 27-30). Box B: Households' investor property exposures. RBA Financial Stability Review.

Reserve Bank of New Zealand. (2016, July). Consultation Paper: Adjustments to restrictions on high-LVR residential mortgage lending. 


\section{Graph Data Sources}

Australian Bureau of Statistics (ABS). (2017). 5220.0 - Australian National Accounts: State Accounts, 2016-17. http://www.abs.gov.au/AUSSTATS/abs@.nsf/DetailsPage/5220.0201617? OpenDocument

Australian Bureau of Statistics (ABS). (2018). 5204.0 - Australian System of National Accounts, 2017-18. http://www.abs.gov.au/AUSSTATS/abs@.nsf/DetailsPage/5204.0201718?OpenDocument

Australian Prudential Regulation Authority (APRA). (2018). https://www.apra.gov.au/publica tions/quarterly-authorised-deposit-taking-institution-property-exposures

Bank for International Settlements (BIS). (2018). Consolidated banking statistics. Accessed June 1, 2018, from https://www.bis.org/statistics/consstats.htm

CoreLogic. (2018). RP Data subscription. https://www.corelogic.com.au/

International Monetary Fund (IMF). (2018). Financial soundness indicators. http://data.imf.org/? $\mathrm{sk}=$ 51B096FA-2CD2-40C2-8D09-0699CC1764DA\&sId=1390030341854

National central banks and statistical offices (various):

Bank of England. (2018). Bankstats tables. https://www.bankofengland.co.uk/statistics/tables

Statistics Canada. (2018). https://www150.statcan.gc.ca/n1/en/type/data?MM=1

Statistics Netherlands. (2018). StatLine. https://opendata.cbs.nl/statline/\#/CBS/en/

US Federal Reserve. (2018). https://www.federalreserve.gov/data/mortoutstand/current.htm

OECD. (2018). Household Debt. Accessed June 1, 2018, from http://www.oecd.org/sdd/na/ householddebt.htm

Reserve Bank of Australia (RBA). (2018). Financial aggregates. https://www.rba.gov.au/statistics/ frequency/fin-agg/2018/

Open Access This chapter is licensed under the terms of the Creative Commons Attribution 4.0 International License (http://creativecommons.org/licenses/by/4.0/), which permits use, sharing, adaptation, distribution and reproduction in any medium or format, as long as you give appropriate credit to the original author(s) and the source, provide a link to the Creative Commons licence and indicate if changes were made.

The images or other third party material in this chapter are included in the chapter's Creative Commons licence, unless indicated otherwise in a credit line to the material. If material is not included in the chapter's Creative Commons licence and your intended use is not permitted by statutory regulation or exceeds the permitted use, you will need to obtain permission directly from the copyright holder.

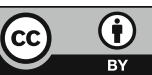

